\title{
Prevalence of Listeria species in camel sausages from retail markets in Aydin province in Turkey and RAPD analysis of Listeria monocytogenes isolates
}

\author{
Gokben Ozbey', Hasan Basri Ertas² and Filiz Kok ${ }^{3}$ \\ 1 Vocational School of Health Services, University of Firat, 231 I 9 Elazig/Turkey \\ 2 Department of Microbiology, Faculty of Veterinary Science, University of Firat, 23 I I 9 Elazig/Turkey \\ ${ }^{3}$ Department of Food Science and Technology, Faculty of Veterinary Science, University of Adnan Menderes, 090 I 6 Isıklı, Aydin/Turkey
}

Samples were taken from 100 camel sausages from the different retail markets in Aydin province in the south-west of Turkey and they were tested for the presence of Listeria spp by biochemical methods. Samples were enriched using Listeria Enrichment Broth and they were inoculated onto Listeria Selective Agar. Listeria monocytogenes was isolated from nine samples (9\%), Listeria innocua from I 4 samples (14\%) and Listeria welshimeri from two samples(2\%). A 70 Ibp fragment of listeriolysin $O$ sequence for L. monocytogenes was amplified using specific primers by polymerase chain reaction (PCR) for confirmation of the identification. A random primer (OPA-II) was used in a random amplified polymorphic DNA (RAPD) assay. This detected five different band profiles amongst the $L$. monocytogenes isolates, indicating a relatively large amount of genetic heterogeneity amongst the nine isolates. The study has highlighted the need for improved strategies for food safety, in particular appropriate hygienic precautions to avoid contamination of sausage during the manufacturing process and appropriate preservation techniques during storage and transport, to prevent transmission of Listeria spp to consumers at home and abroad.

Irish Veterinary Journal

Volume 59 (6) 342-344, 2006

Keywords: Camel sausage, Listeria monocytogenes, PCR, RAPD

\section{Introduction}

A wide variety of meats and meat products, including fermented sausages, can be contaminated with Listeria spp (Johnson et al., 1990). L. monocytogenes is known to survive the commercial dry sausage manufacturing process (Incze, 1998). In Turkey, Ciftcioglu (1992) found Listeria spp in $11 \%$ of sausages, with $L$. monocytogenes in $2 \%$ and $L$. innocua in $8 \%$. A subsequent study by Guven and Patir (1998) found Listeria spp in $16.3 \%$ of sausages, with L. monocytogenes in $11.9 \%$ and L. innocua in $11.3 \%$.

Several molecular genotyping methods have been used to type $L$. monocytogenes, such as DNA restriction endonuclease analysis (Wesley and Ashton, 1991), multilocus enzyme electrophoresis (Bibb et al., 1990), ribotyping (Baloga and Harlander, 1991) and pulsedfield gel electrophoresis (PFGE) (Autio et al., 1999). However, these methods are not well suited for routine use in laboratories and are time-consuming. PFGE is very discriminative, but it is labour-intensive

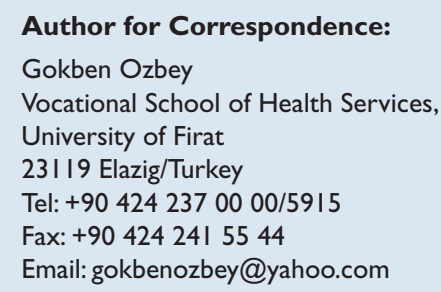

and requires expensive apparatus (Franciosa et al., 1998). RAPD typing is suitable for differentiation of the most commonly found serotypes and for screening large panels of strains (Byun et al., 200 I).

The aims of this study were to determine the prevalence of Listeria spp in camel sausages at different retail markets in Aydin provience in the south-west of Turkey, to analyse genetic variability among L. monocytogenes isolates by RAPD using a random primer and to enquire whether there is a public health risk of acquiring listeriosis from consumption of camel sausage.

\section{Materials and methods \\ Material}

Samples were taken from 100 camel sausages obtained from the different retail markets in Aydin province, in the south-west of Turkey.

\section{Detection of Listeria spp}

For microbiological analysis, the sausage casing was removed aseptically. A $25 \mathrm{~g}$ sample from each sausage was added to $225 \mathrm{ml}$ of Listeria Enrichment Broth (LEB, Oxoid) and homogenised in a stomacher (Interscience, 78860 St Nom-France) at high speed, for one minute at room temperature and incubated at $37^{\circ} \mathrm{C}$ for 24 hours (primary enrichment). Then, an aliquot of $0.1 \mathrm{ml}$ of the culture was transferred into tubes containing $10 \mathrm{ml}$ LEB. The tubes were incubated for 24 hours to 48 hours at $37^{\circ} \mathrm{C}$ (secondary enrichment). A loopful of each enrichment culture was streaked onto Listeria Selective Agar (LSA, Oxoid) and was incubated for 24 hours, at $37^{\circ} \mathrm{C}$. The suspected 
colonies with a dark brown colour or black halo were transferred onto tryptic soy agar (TSA, Difco) and incubated for 24 hours, at $37^{\circ} \mathrm{C}$. The isolates were identified using conventional methods: Gram staining; the Christie, Atkins, Munch-Petersen (CAMP) test; typical umbrella motility; and fermentation of mannitol, rhamnose and xylose (Seeliger et al., 1986).

\section{Extraction of DNA}

A few colonies from cultures were transferred into an Eppendorf tube containing $300 \mu \mathrm{l}$ of distilled water and the tubes were vortexed. Lysis was accomplished by the addition of $300 \mu$ l of TNES buffer (20mM Tris- $\mathrm{HCl} \mathrm{pH} 8.0,150 \mathrm{mM} \mathrm{NaCl}, 10 \mathrm{mM}$ EDTA, $0.2 \%$ SDS) and $200 \mu \mathrm{g} / \mathrm{ml}$ Proteinase K. The lysis mixture was incubated at $37^{\circ} \mathrm{C}$ for two hours and boiled for 30 minutes. Bacterial DNA was extracted by the phenol:chloroform:isoamylalcohol procedure. All purifications and PCR reactions used L. monocytogenes serovar I/2a: CIP I04794/ ATCC-35I52 (obtained from Pasteur Institute) as the positive control and distilled water as the negative control.

\section{Primers}

Primers used in this study were designed by Border et al. (1990).

The sequences of primer pairs were as follows: LMI (5'- CCT AAG ACG CCA ATC GAA - 3') and LM2 (5'- AAG CGC TTG CAA CTG CTC - 3'). These primers amplify a 70I bp fragment on listeriolysin $O$ sequence of $L$. monocytogenes.

PCR

PCR reactions were performed in a reaction mixture $(50 \mu)$ final volume) containing $5 \mu \mathrm{l}$ of $10 \times \mathrm{PCR}$ buffer $(10 \mathrm{mM}$ Tris $-\mathrm{HCl}, \mathrm{pH}$ $9.0,50 \mathrm{mM} \mathrm{KCl}, 0.1 \%$ Triton $\mathrm{X}-100$ ), $5 \mu \mathrm{l}$ of $25 \mathrm{mM} \mathrm{MgCl} 2,250 \mu \mathrm{M}$ of each deoxynucleoside triphosphate, $2 U$ of Taq DNA polymerase (Fermentas, Lithuania), $50 \mathrm{pmol}$ of each primer and $5 \mu \mathrm{l}$ of template sample DNA. Amplification was obtained with an initial denaturation step at $94^{\circ} \mathrm{C}$ for five minutes, followed by 45 cycles at $94^{\circ} \mathrm{C}$ for 30 seconds, $52^{\circ} \mathrm{C}$ for one minute and $72^{\circ} \mathrm{C}$ for one and a half minutes. The final cycle was at $72^{\circ} \mathrm{C}$ for seven minutes. For all experiments, a Touchdown Thermocycler (Hybaid, Middlesex, England) was used. Ten $\mu \mathrm{l}$ of amplified products were detected by electrophoresis in I.5\% agarose, in I X Tris-borate-EDTA buffer. Gels were stained with ethidium bromide $(0.5 \mu \mathrm{g} / \mathrm{ml})$. The DNA fragments were visualised by UV illumination and photographed with Polaroid film. The molecular sizes of the PCR products were compared with a 100bp DNA ladder.

\section{RAPD analysis}

The RAPD reaction mixture was prepared in a total volume of $25 \mu \mathrm{l}$ consisting of $2.5 \mu \mathrm{l}$ of $10 x P C R$ buffer $(750 \mathrm{mM}$ Tris- $\mathrm{HCl}, 200 \mathrm{mM}$ $\left[\mathrm{NH}_{4}\right]_{2} \mathrm{SO}_{4}, 0.1 \%$ Tween $\left.20, \mathrm{pH} 8.8\right), 3.5 \mathrm{mM} \mathrm{MgCl}, 200 \mu \mathrm{M}$ of each deoxynucleoside triphosphates, I.25U of Taq DNA polymerase (Fermentas, Lithuania), I $\mu$ M of OPA-II primer (5'-CA AT CG CC GT-3'), II $\mu \mathrm{l}$ of $\mathrm{ds}_{2} \mathrm{O}$ (sterile distilled water) and $2.5 \mu \mathrm{l}$ of template DNA. Each sample was amplified through 50 cycles of denaturation (one minute at $94^{\circ} \mathrm{C}$ ), primer annealing (one minute at $37^{\circ} \mathrm{C}$ ) and extension (one minute at $72^{\circ} \mathrm{C}$ ). A last cycle of extension was applied at $72^{\circ} \mathrm{C}$ for 10 minutes. Twenty microlitres of product was resolved by electrophoresis on a $2 \%$ agarose gel in Tris-borate EDTA buffer and visualised by staining with $0.5 \mu \mathrm{g} / \mathrm{ml}$ ethidium bromide for 30 minutes. The agarose gels were photographed under UV light. A I kb DNA ladder (Promega, Maddison, USA) was used as a molecular size standard. RAPD assays were performed at least three times each to check reproducibility.

\section{Results}

\section{Culture and PCR}

Of the 100 camel sausage samples, nine $(9 \%)$ contained $L$. monocytogenes, 14 (14\%) contained L. innocua and 2 (2\%) contained $L$. welshimeri. A $70 \mathrm{lbp}$ fragment was amplified from all the tested $L$. monocytogenes strains identified by conventional procedures (Figure I), but not from the negative control.

RAPD

RAPD typing using OPA-II primer detected five different band profiles (a, b, c, d,e) on nine isolates of L. monocytogenes (Figure 2 ).

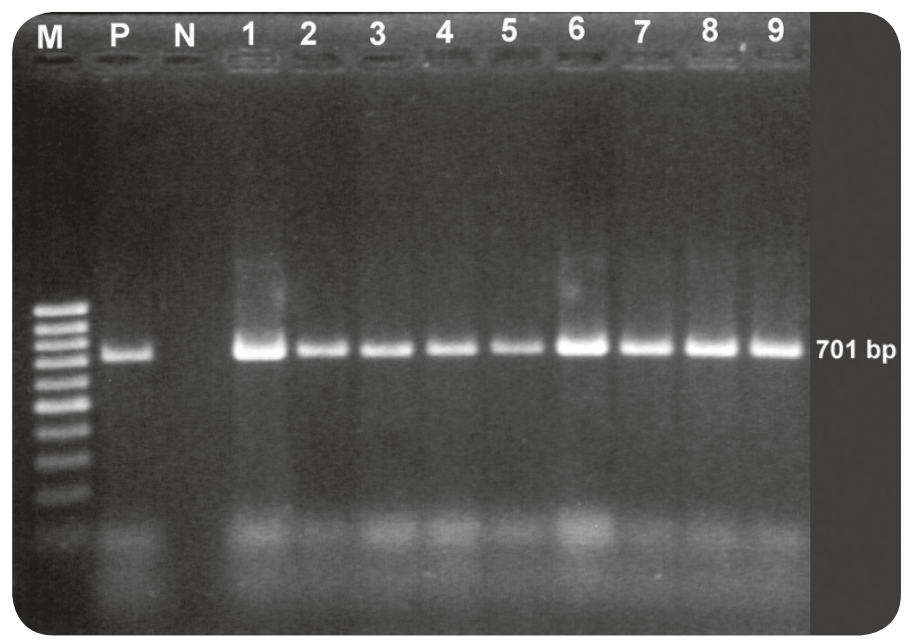

Figure I: An agarose gel stained with ethidium bromide, with $\mathrm{PCR}$ products of $L$. monocytogenes isolates from sausages (M: 100 bp DNA ladder, P: positive control, N: negative control, lanes I-9: L. monocytogenes isolates).

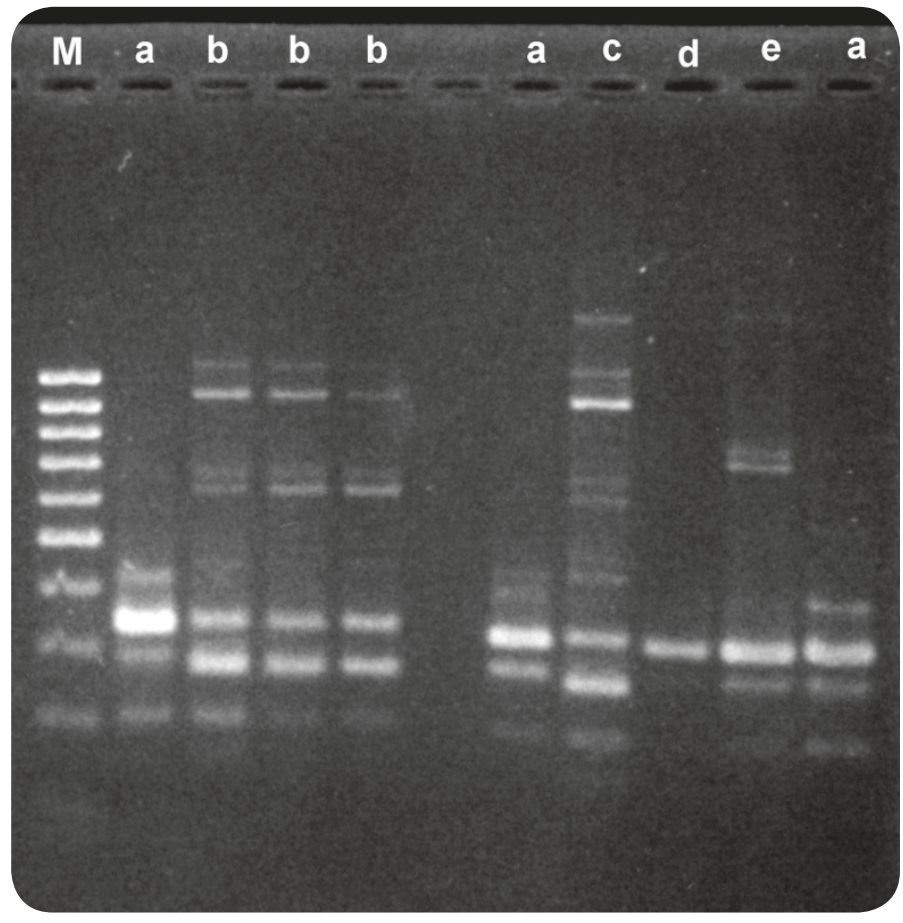

Figure 2: RAPD analysis of $L$. monocytogenes isolates from sausages (M: 100 bp DNA ladder, lanes a, b, c, d, e: profiles). 


\section{Discussion}

Studies carried out in different parts of Turkey have found Listeria spp in 11\% (Ciftcioglu, 1992) to 16.3\% (Guven and Patir, 1998) of sausages. In some other countries prevalence has been reported to be considerably higher (Breer and Schopfer, 1989; Farber et al., 1989). In the present study, Listeria spp were obtained from $25 \%$ of the sampled sausages. In this and in other studies, three Listeria species have been identified: $L$. innocua, $L$. monocytogenes and $L$. welshimeri (Breuer and Prandl, 1988; Schmidt et al., 1988; Guven and Patir, 1998; Paziak-Domanska et al., 1999; Uyttendeale et al., 1999). In the present study, all the isolates of $L$. monocytogenes were successfully typed by the RAPD method using only OPA-II primer. One random primer was used and five different profiles were observed, thus indicating a large amount of genetic heterogeneity amongst the nine isolates of $L$ monocytogenes.

Overall, $L$. innocua has been isolated from sausage more frequently than have the other two species. For instance, Paziak-Domanska et al. (1999) recovered Listeria from I5 samples of sausage, L. innocua from 10 samples, L. monocytogenes from three samples and L. welshimeri from two samples. A similar trend was evident in the present study: $L$. innocua from 14 samples, $L$. monocytogenes from nine samples and $L$. welshimeri from two samples.

In summary, this study revealed the presence of Listeria spp in a significant proportion (25\%) of samples of camel sausage on sale in different retail markets in Aydin province in the south-west of Turkey. It has indicated that a large amount of genetic heterogeneity exists among $L$. monocytogenes isolates from camel sausage. Thus, it has highlighted the need for improved strategies for food safety, in particular appropriate hygienic precautions to avoid contamination during the manufacturing process and appropriate preservation techniques during storage and transport to prevent transmission of Listeria spp to consumers at home and abroad.

\section{References}

Autio, T., Hielm, S., Miettinen, M., Sjoberg, A.M., Aarnisalo, K., Bjorkroth, J., Mattila-Sandholm, T. and Korkeala, H. (1999). Sources of Listeria monocytogenes contamination in a coldsmoked rainbow trout processing plant detected by pulsed-field gel electrophoresis typing. Applied and Environmental Microbiology 65: I50155.

Baloga, A.O. and Harlander, S.K. (1991). Comparison of methods for discrimination between strains of Listeria monocytogenes from epidemiological surveys. Applied and Environmental Microbiology 57: 2324-233I.

Bibb, W.F., Gelin, B.G., Weaver, R., Schwartz, B., Plikaytis, B.D., Reeves, M.W., Pinner, R.W., Claire, V. and Broome, C.V. (1990). Analysis of clinical and food-borne isolates of Listeria monocytogenes in the United States by multilocus enzyme electrophoresis and application of the method to epidemiological investigations. Applied and Environmental Microbiology 6:2133-2141.

Border, P.M., Howard, J.J., Plastow, G.S. and Siggens, K.W. (1990). Detection of Listeria species and Listeria monocytogenes using polymerase chain reaction. Letters in Applied Microbiology I I: I 58-I62.

Breer, C. and Schopfer, K. (1989). Listerien in Nahrungsmitteln. Schweizerische Medizinische Wochenschrift I I 9: 306-3II.

Breuer, V.J. and Prandl, O. (1988). Nachweis von Listerien und deren vorkommen in hackfleisch und mettwürsten österreich. Archiv für Lebensmittelhygiene 39:28-30.

Byun, S.K., Jung, S.C. and Yoo, H.S. (200I). Random amplification of polymorphic DNA typing of Listeria monocytogenes isolated from meat. International Journal of Food Microbiology 69: 227-235.

Ciftcioglu, G. (1992). Investigations on presence of Listeria monocytogenes in minced meat, sausage and meats. PhD Thesis, University of Istanbul, Istanbul, Turkey.

Farber, J.M., Sanders, G.W. and Johnston, M.A. (1989). A survey of various foods for the presence of Listeria species. Journal of Food Protection 52: 456-458.

Franciosa, G., Pourshaban, M., Gianfranceschi, M. and Aureli, P. (1998). Genetic typing of human and food isolates of Listeria monocytogenes from episodes of listeriosis. European Journal of Epidemiology I4: 205-210.

Guven, A. and Patir, B. (1998). Studies of the Listeria species in some meat and meat products consumed in Elazig city. Turkish Journal of Veterinary and Animal Sciences 22: 205-212.

Incze, K. (1998). Dry fermented sausages. Meat Science 49 Supplement I: I69-I77.

Johnson, J.L., Doyle, M.P. and Cassens, R.G. (1990). Listeria monocytogenes and Listeria spp in meat and meat products. A review. Journal of Food Protection 53: 8I-9I.

Paziak-Domanska, B., Boguslawska, E., WieckowskaSzakiel, M., Kotlowski, R., Rózalska, B., Chmiela, M., Kur, J., Dabrowski, W. and Rudnicka, W. (1999). Evaluation of the API test, phosphatidylinositol-specific phospholipase C activity and PCR method in identification of Listeria monocytogenes in meat foods. FEMS Microbiology Letters I7 I: 209-2I4.

Schmidt, U., Seeliger, H.P.R., Glenn, E., Langer, B. and Leistner, L. (1988). Listerienfunde in rohen fleischerzeugnissen. Fleischwirtschaft 68: $|3| 3-13 \mid 6$.

Seeliger, H.P.R. and Jones, D. (1986). Genus Listeria. IN: O.Kandler and N.Weiss (eds.) Bergey's Manual of Systematic Bacteriology. Second edition. Baltimore:Williams and Wilkins. pp I235- 245.

Uyttendaele, M., De Troy, P. and Debevere, J. (1999). Incidence of Listeria monocytogenes in different types of meat products on the Belgian retail market. International Journal of Food Microbiology 53: 7580.

Wesley, I.V. and Ashton, F. (1991). Restriction enzyme analysis of Listeria monocytogenes strains associated with food-borne epidemics. Applied and Environmental Microbiology 57:969-975. 